\title{
To mask or not to mask children to overcome COVID-19
}

\author{
Susanna Esposito ${ }^{1,2}$ (ID $\cdot$ Nicola Principi ${ }^{3}$
}

Received: 18 April 2020 / Revised: 26 April 2020 / Accepted: 29 April 2020 / Published online: 9 May 2020

(C) Springer-Verlag GmbH Germany, part of Springer Nature 2020

\begin{abstract}
It has been reported that asymptomatic people can transmit the new coronavirus disease 2019 (COVID-19) and become important sources of COVID-19. To reduce the role of asymptomatic or poorly symptomatic people in COVID-19, universal use of face masks in addition to hand hygiene and safety distance seems extremely useful. Consequently, preparing the healthy child to use face masks is strongly needed. To obtain maximal compliance, reasons for mask wearing without attempts of removing must be clearly explained. Moreover, child's will must not be forced.

Conclusion: On the basis of clinical findings, we think that the universal use of facial masks seems necessary when people have to go out in their everyday lives. In addition to the availability of masks of different sizes capable of adapting perfectly to the face, it is necessary that the use of masks in children is preceded by a strong parental work and school lessons on this issue and other hygiene topics with the main aim to obtain child cooperation.
\end{abstract}

\section{What is Known:}

- Asymptomatic people can transmit and become important sources of COVID-19.

- Asymptomatic cases are common also in pediatrics.

What is New:

- Universal use of face masks for success against COVID-19 seems necessary also in pediatric age when people have to go out in their everyday lives.

- In addition to the availability of masks of different sizes capable of adapting perfectly to the face, it is necessary that the use of masks in children is preceded by a strong parental work and school lessons with the main aim to obtain child cooperation.

Keywords COVID-19 $\cdot$ Face mask $\cdot$ SARS-CoV-2 $\cdot$ Surgical mask

\section{Abbreviations \\ COVID-19 New coronavirus disease 2019 \\ SARS-CoV-2 Severe acute respiratory syndrome coronavirus 2}

Until recently, it was supposed, according to a World Health Organization report from February 2020 [1], that the proportion of truly asymptomatic carriers of severe acute respiratory

Communicated by Peter de Winter

Susanna Esposito

susannamariaroberta.esposito@unipr.it; susanna.esposito@unimi.it

Nicola Principi

nicola.principi@unimi.it

1 Pediatric Clinic, Pietro Barilla Children's Hospital, Via Gramsci 14, 43126 Parma, Italy

2 Department of Medicine and Surgery, University of Parma, Via Gramsci 14, 43126 Parma, Italy

3 Università degli Studi di Milano, Milan, Italy syndrome coronavirus 2 (SARS-CoV-2) infection was relatively small and not a major driver of virus circulation, infection transmission, and new disease development. However, recently collected data seem to completely negate this statement. In a study carried out in an isolated village of approximately 3000 people in northern Italy, it was shown that 50-75\% of people with positive pharyngeal molecular tests were totally asymptomatic [2]. This finding was confirmed by a more recent evaluation carried out in China, where to avoid a new outbreak of new coronavirus disease 2019 (COVID-19), all the people arriving from overseas were rigorously tested [3]. It was found that among patients with newly identified infections, $78 \%$ were asymptomatic. Although few, data collected in children seem to indicate that asymptomatic cases are common also in pediatrics. An observational cohort study enrolling 36 children aged $0-16$ years (mean, 8.3 years) with laboratory confirmed COVID-19 revealed that 10 of them (28\%) were totally asymptomatic [4]. Similar findings were reported in a study enrolling a greater number of COVID-19 children (mean age, 6.7 years), in which it was evidenced that among 171 patients, 27 (15.8\%) were asymptomatic [5]. Although the 
amount of viral load associated with SARS-CoV-2 transmission is not known and viral shedding increases with increasing COVID-19 severity [6], it seems likely that at least some asymptomatic people of any age can transmit the infection and become important sources of new COVID-19 cases.

In addition, cases of certain transmission of SARS-CoV-2 infection from an asymptomatic contact have been described $[6,7]$. Contrarily to adults and old people that frequently have moderate or severe clinical manifestations, about $50 \%$ of symptomatic children have a mild disease that tends to solve spontaneously and does not require medical intervention [8]. These cases are not recognized often as COVID-19 but can contribute to increase virus circulation and new COVID-19 case development.

To reduce the role of asymptomatic or poorly symptomatic people in SARS-CoV-2 diffusion, the Centers for Disease Control and Prevention in the USA has modified previous recommendations, suggesting that, together with infected persons and health care workers, healthy people "should wear a cloth face cover when they have to go out in public, for example, to the grocery store or to pick up other necessities" [9]. The need for universal use of cloth face coverings or, when available, of surgical masks seems further suggested by the results of some studies that support the hypothesis that face masks are effective in reducing the presence of viral particles in droplets and aerosol generated by symptomatic SARSCoV-2-infected individuals [10].

Until some weeks ago, it was thought that the virus could be transmitted mainly by droplets that are coughed or sneezed out or by previously contaminated objects, with differences according to the initial load and surface characteristics [11]. Airborne transmission of SARS-CoV-2 was considered possible only when care procedures that generate aerosols, such as intubation, bronchoscopy, and positive-pressure ventilation, are performed [12]. However, the results of some submitted but not yet peer-reviewed studies seem to indicate the opposite, i.e., the virus can be present in exhaled air produced by talking and breathing [13]. Moreover, a potential role of aerosols in virus diffusion was evident in a complex laboratory study. Aerosols containing a viral load quite similar to that observed in human respiratory samples were created to generate an aerosolized environment. SARS-CoV-2 was detected up to $3 \mathrm{~h}$ after the start of the study [14]. Although these findings were not considered fully convincing by some authors [11], they deserve attention and require further studies to establish whether and when airborne transmission of SARS-CoV-2 truly occurs and how it can be reduced. The maximal distance between persons that still allow airborne transmission, the size of aerosolized particles that are generated, the lowest infection dose, and how long a person must remain in a room containing aerosols with the virus to become infected are among the problems that must be solved to evaluate the real importance of air transmission problems and make decisions on preventive measures. Answers to these questions are essential to establish whether surgical masks that are suggested for the prevention of infection due to asymptomatic subjects can also be effective for the prevention of airborne transmission.

Table 1 summarizes the different types of face masks and which could be good or not for children in the community. Whereas the effectiveness of homemade cloth face coverings is debated, it is well known that surgical masks can prevent the inhalation of large droplets and sprays, although they have a poor ability to filter submicron-sized airborne particles [15]. As airborne transmission refers to particles $<5 \mu \mathrm{m}$ in diameter, it cannot be determined whether they are always effective, at least when they are properly used. On the other hand, in some cases, such as those with very small particles and a high viral load, surgical masks could fail and allow infection diffusion. To solve the problem, the size of SARS-CoV-2 aerosolized particles produced by cough, sneeze, talking, and breathing should be determined. However, in favor of surgical masks, there are studies that were carried out in the prevention of influenza, a viral disease with some similarities with COVID-19, and during the SARS epidemic. A metaanalysis of randomized controlled trials comparing surgical masks and N95 respirators in preventing influenza-like illness and laboratory-confirmed influenza showed that these two preventive measures were similarly effective [16]. Similar

Table 1 Different types of face masks and which could be good or not for children in the community

\begin{tabular}{|c|c|c|}
\hline $\begin{array}{l}\text { Type of } \\
\text { mask }\end{array}$ & Characteristic & $\begin{array}{l}\text { Comments for the pediatric } \\
\text { population in the community }\end{array}$ \\
\hline $\begin{array}{l}\text { Cloth } \\
\text { mask }\end{array}$ & $\begin{array}{l}\text { Cloth face mask covering } \\
\text { over nose and mouth in the } \\
\text { community setting to } \\
\text { reduce the possibility that } \\
\text { someone with no } \\
\text { symptoms could transmit } \\
\text { the disease to others }\end{array}$ & $\begin{array}{l}\text { Homemade or purchased } \\
\text { cloth masks are suitable for } \\
\text { the average person to wear. } \\
\text { For a small child, ensuring } \\
\text { the right fit is important. } \\
\text { Children younger than age } \\
2 \text { should not wear masks. }\end{array}$ \\
\hline $\begin{array}{c}\text { Surgical } \\
\text { mask }\end{array}$ & $\begin{array}{l}\text { Loose-fitting, disposable } \\
\text { device that creates a } \\
\text { physical barrier between } \\
\text { the mouth and the nose of } \\
\text { the wearer and potential } \\
\text { contaminants in the } \\
\text { immediate environment }\end{array}$ & $\begin{array}{l}\text { Available of smaller size for } \\
\text { children } \geq 3 \text { years old }\end{array}$ \\
\hline $\begin{array}{l}\text { N95 } \\
\quad \text { respi- } \\
\text { rator }\end{array}$ & $\begin{array}{l}\text { Personal protective } \\
\text { equipment that are used to } \\
\text { protect the wearer from } \\
\text { airborne particles and from } \\
\text { liquid contaminating the } \\
\text { face }\end{array}$ & $\begin{array}{l}\text { Not recommended for the } \\
\text { general population. Only } \\
\text { children who are } \\
\text { considered high-risk for } \\
\text { severe complications or } \\
\text { severely immunocompro- } \\
\text { mised are encouraged to } \\
\text { wear an N95 mask to best } \\
\text { protect themselves. }\end{array}$ \\
\hline
\end{tabular}


results were obtained in a retrospective study carried out in five Hong Kong hospitals in which the effect of surgical masks and N95 respirators in the prevention of SARS among health care workers was compared. Even in this case, no difference was evidenced between the two masks [17]. On the other hand, wearing N95 respirators that are designed to achieve a very close facial fit and that can block $0.3-\mu \mathrm{m}$ particles is associated with an increased effort in breathing, leading to discomfort, tiredness, or headaches after few hours of use. This explains why the use of N95 respirators is recommended only for health care workers that must take care of infected patients and can be exposed to aerosolized particles of very small size [18].

However, protecting healthy children with a mask can be very difficult. It is recommended that children younger than 2 years of age do not wear any type of mask as they, having very small airways, can struggle to breathe. Moreover, as they can be unable to remove the mask without assistance, they are at increased risk of suffocation [19]. For infants, particularly the youngest, social distancing remains, together with washing hands and avoiding licking things, the measure of choice to reduce risk of SARS-CoV-2 infection as highlighted by the American Academy of Pediatrics [20]. Surgical masks of smaller size suitable for children from 3 to 12 years old are marketed. Moreover, according to the US Centers for Disease Prevention and Control [19], they can be prepared at home from common materials at low cost. However, in toddlers and children of the first school years, frequently masks do not fit snugly on the face with the risk that contaminated air can access or mask is poorly tolerated. Moreover, as generally children do not like to keep the mask on and will likely try to remove it, as well as touch their face more, the use of mask can favor infection development. Consequently, preparing the healthy child to use the mask is strongly needed if problems must be avoided. To obtain maximal compliance, reasons for mask wearing without attempts of removing it must be clearly explained. Finally, child's will must not be forced.

While waiting for the results of the abovementioned studies on the transmission of SARS-CoV-2, on the basis of clinical findings, we think that the universal use of facial masks seems necessary when people have to go out in their everyday lives. However, the use in children poses a whole series of problems that are not easily solved. In addition to the availability of masks of different sizes capable of adapting perfectly to the face, it is necessary that the use of masks in children is preceded by a strong parental work with the main aim to obtain child cooperation. This seems particularly important for healthy subjects that have to wear the mask for the first time. Children with chronic respiratory disease, such as those with cystic fibrosis, that are used to use mask have less problems. If compliance is difficult, it is better that the child does not wear the mask, and other measures or reducing infection risk, including remaining at home, are practiced. A systematic adoption of face masks might have important implication for the opening of schools, and schools should focus some lessons on this issue to favor the use of masks among children and support parents in this work. On the other hand, in addition to face masks, the other measures of COVID-19 prevention such as safety distance or hand washing, despite not always easy with children, should not be forgotten especially in schools.

Authors' contributions S.E. and N.P. co-wrote the manuscript, and both authors approved the text.

\section{Compliance with ethical standards}

Conflict of interest The authors declare that they have no conflict of interest.

Ethical approval This article does not contain any studies with human participants or animals performed by any of the authors.

Informed consent Not applicable.

\section{References}

1. World Health Organization (2020) Report of the WHO-China Joint Mission on coronavirus disease 2019 (COVID-19). https://www. who.int/docs/default-source/coronaviruse/who-chinajoint-missionon-covid-19-final-report.pdf. Accessed 3 April 2020

2. Day M (2020) Covid-19: identifying and isolating asymptomatic people helped eliminate virus in Italian village. BMJ 368:m1165

3. Day M (2020) Covid-19: four fifths of cases are asymptomatic, China figures indicate. BMJ 369:m1375

4. Qiu H, Wu J, Hong L, Luo Y, Song Q, Chen D (2020) Clinical and epidemiological features of 36 children with coronavirus disease 2019 (COVID-19) in Zhejiang, China: an observational cohort study. Lancet Infect Dis. https://doi.org/10.1016/S1473-3099(20) 30198-5

5. Lu X, Zhang L, Du H, Zhang J, Li YY, Qu J et al (2020) SARSCoV-2 infection in children. N Engl J Med. https://doi.org/10.1056/ NEJMc2005073

6. Zhou F, Yu T, Du R, Fan G, Liu Y, Liu Z et al (2020) Clinical course and risk factors for mortality of adult inpatients with COVID-19 in Wuhan, China: a retrospective cohort study. Lancet. https://doi.org/ 10.1016/S0140-6736(20)30566-3

7. Zimmer T, Thiel V, Janke C, Bretzel G, Froeschl G, Wallrauch C et al (2020) Transmission of 2019-nCoV infection from an asymptomatic contact in Germany. N Engl J Med 382:970-971

8. Dong Y, Mo X, Hu Y, Qi X, Jiang F, Jiang Z et al (2020) Epidemiology of COVID-19 among children in China. Pediatrics. https://doi.org/10.1542/peds.2020-0702

9. Centers for Disease Control and Prevention. Coronavirus disease 2019 (COVID-19). How to protect yourself \& others. https://www. cdc.gov/coronavirus/2019-ncov/prevent-getting-sick/prevention. html. Accessed 3 April 2020

10. Leung NHL, Chu DKW, Shiu EYC, Chan KH, McDevitt JJ, Hau BJP et al (2020) Respiratory virus shedding in exhaled breath and efficacy of face masks. Nat Med. https://oi.org/10.1038/s41591020-0843-2

11. World Health Organization. Modes of transmission of virus causing COVID-19: implications for IPC precaution recommendations. 
https://www.who.int/news-room/commentaries/detail/modes-oftransmission-of-virus-causing-covid-19-implications-for-ipcprecaution-recommendations Accessed 3 April 2020

12. Lewis D Is the coronavirus airborne? Experts can't agree. Nature. https://www.nature.com/articles/d41586-020-00974-w. Accessed 3 April 2020

13. van Doremalen N, Bushmaker T, Morris DH, Holbrook MG, Gamble A, Williamson BN et al (2020) Aerosol and surface stability of SARS-CoV-2 as compared with SARS-CoV-1. N Engl J Med. https://doi.org/10.1056/NEJMc2004973

14. Derrick JL, Gomersall CD (2005) Protecting healthcare staff from severe acute respiratory syndrome: filtration capacity of multiple surgical masks. J Hosp Infect 59:365-368

15. University of Maryland (2020) Wearing surgical masks in public could help slow COVID-19 pandemic's advance: masks may limit the spread diseases including influenza, rhinoviruses and coronaviruses. ScienceDaily. www.sciencedaily.com/releases/ 2020/04/200403132345.htm. Accessed 3 April 2020

16. Long Y, Hu T, Liu L, Chen R, Guo Q, Yang L et al (2020) Effectiveness of N95 respirators versus surgical masks against influenza: a systematic review and meta-analysis. J Evid Based Med. https://doi.org/10.1111/jebm.12381
17. Seto WH, Tsang D, Yung RW, Ching TY, Ng TK, Ho M, Ho LM, Peiris JS, Advisors of Expert SARS group of Hospital Authority (2003) Effectiveness of precautions against droplets and contact in prevention of nosocomial transmission of severe acute respiratory syndrome (SARS). Lancet 361:1519-1520

18. Centers for Disease Control and Prevention. Coronavirus disease 2019 (COVID-19). Strategies for optimizing the supply of N95 respirators. https://www.cdc.gov/coronavirus/2019-ncov/hcp/ respirators-strategy/index.html Accessed 19 April 2020

19. Centers for Disease Control and Prevention. Coronavirus disease 2019 (COVID-19). Use of cloth face coverings to help slow the spread of COVID-19. https://www.cdc.gov/coronavirus/2019ncov/prevent-getting-sick/diy-cloth-face-coverings.html. Accessed 9 April 2020

20. American Academy of Pediatrics. Masks and children during COVID-19. https://services.aap.org/en/pages/2019-novelcoronavirus-covid-19-infections/masks-and-children-duringcovid-19/ Accessed 9 April 2020

Publisher's note Springer Nature remains neutral with regard to jurisdictional claims in published maps and institutional affiliations. 